\title{
Development and clinical application of anti-HER2 monoclonal and bispecific antibodies for cancer treatment
}

\author{
Shengnan Yu', Qian Liu', Xinwei Han², Shuang Qin ${ }^{1}$, Weiheng Zhao ${ }^{1}$, Anping $\mathrm{Li}^{2 *}$ and Kongming Wu${ }^{1 *}$
}

\begin{abstract}
HER2-targeted immunotherapy consists of monoclonal antibodies (e.g. trastuzumab, pertuzumab), bispecific antibodies (e.g. MM-111, ertumaxomab) and activated T cells armed with anti-HER2 bispecific antibody (HER2Bi-aATC). Trastuzumab is a classic drug for the treatment of HER2 positive metastatic breast cancer. The combined application of pertuzumab, trastuzumab and paclitaxel has been suggested as a standard therapy for HER2 positive advanced breast cancer. The resistance to anti-HER2 antibody has resulted in disease progression. HER2-directed bispecific antibody may be a promising therapeutic approach for these patients. Ertumaxomab enhanced the interaction of immune effector cells and tumor cells. MM-111 simultaneously binds to HER2 and HER3 and blocks downstream signaling. Besides, HER2Bi-aATC is also an alternative therapeutic approach for HER2 positive cancers. In this review, we summarized the recent advancement of HER2-targeted monoclonal antibodies (trastuzumab, pertuzumab and T-DM1) and bispecific antibodies (MM-111, ertumaxomab and HER2Bi-aATC), especially focus on clinical trial results.
\end{abstract}

Keywords: HER2, Trastuzumab, Pertuzumab, T-DM1, Bispecific antibody, Ertumaxomab, MM-111, HER2Bi-aATCs

\section{Background}

Human epithelial growth factor receptor 2 (HER2) belongs to the receptor tyrosine kinase family, which consists of four members: HER1 (also known as EGFR), HER2 (also known as Neu), HER3 and HER4 [1]. HER2 is a $185-\mathrm{kDa}$ transmembrane glycoprotein containing three components: an extracellular ligand binding domain, a transmembrane domain, and an intracellular domain that has tyrosine kinase activity [2]. Amplification of the HER2 gene or overexpression of HER2 receptor plays a crucial role in the cellular transformation, carcinogenesis and prognosis of many cancer types [3]. HER2-positive tumors account for about $20-30 \%$ breast cancer [4], 20\% advanced gastric or gastric or gastro-esophageal junction cancers [5], 5-15\% bladder cancers [6], 5-15\% cervix cancers [7], 12-15\% gallbladder cancers [8], 8-35\%

\footnotetext{
*Correspondence: li_anping@yahoo.com; kmwu@tjh.tjmu.edu.cn 1 Department of Oncology, Tongji Hospital of Tongji Medical College, Huazhong University of Science and Technology, 1095 Jiefang Avenue, Wuhan 430030, China

2 Department of Interventional Radiology, First Affiliated Hospital of Zhengzhou University, Zhengzhou 450052, China
}

endometrium cancers [9], 6-7\% ovarian cancers [10], and $15-37 \%$ salivary duct cancers [11]. Because of this, detection of the expression level of HER2 is conventional and helpful for doctors to diagnose, especially in patients with breast cancer. In addition to evaluate the expression level of HER2 in primary site by immunohistochemistry staining (IHC) or fluorescence in situ hybridization (FISH), detection of circulating tumor cells (CTCs) is also regarded as a promising method [12]. HER2 is considered as an ideal target for antitumor treatment [13, 14]. Unlike other members, HER2 has no any known natural ligand to bind. It exhibits functions through EGFR-HER2 heterodimers, HER2-HER3 heterodimers, and HER2-HER2 homodimers $[15,16]$.

Until now, several HER2-directed therapies have been approved for the HER2-positive breast cancer and non-small cell lung cancer, including trastuzumab, pertuzumab, T-DM1, lapatinib and afatinib (tyrosine kinase inhibitors which blocked EGFR and HER2) [3, 17]. Trastuzumab, as a classical anti-HER2 antibody, blocked homodimerization of HER2 through binding to the domain IV of HER2 [18]. As to pertuzumab, it can 
prevent the formation of heterodimerization via binding to HER2 subdomain II [19]. Because of the distinct but complementary modes of action, combination of the two agents could obviously strengthen the blockage of downstream signaling, including phosphoinositide 3-kinase/ protein kinase $\mathrm{B} /$ mammalian target of rapamycin (PI3K/ Akt/mTOR) and Ras/Raf/mitogen-activated protein kinase (MAPK) [20, 21]. Besides, anti-HER2 monoclonal antibodies could increase endocytosis of HER2 receptor, suppress angiogenesis [22, 23], and induce tumor cell lysis through antibody-dependent cell-mediated cytotoxicity (ADCC) [18] (Fig. 1). Ado-trastuzumab emtansine (T-DM1) is an approved antibody drug conjugate for HER2-positive breast cancer. In addition to having the function of trastuzumab, T-DM1 could release the microtubule-inhibitory agent (DM1) after internalization of HER2/T-DM1 complex [3]. Besides, synergistic antitumor functions of HER2 antibody with other antitumor agents have been observed in both in vitro and in vivo studies $[24,25]$. However, about $70 \%$ patients are resistant to trastuzumab, and some exhibited primary resistance [26, 27]. Aimed at the obstacle, researchers have proposed several corresponding strategies: maintaining trastuzumab therapy after progression [28, 29], combining HER2 inhibitors [30, 31], and developing novel anti-HER2 monoclonal antibodies [32]. Bispecific antibodies, such as blinatumomab, have achieved great success in hematological malignancies [33]. Among those, HER2-targeted bispecific antibodies which introduced to be widely investigated are also regarded as a remarkable solution [34].

Ertumaxomab, an intact bispecific antibody, can target HER2 on tumor cells and CD3 on T cells simultaneously, and activate accessory cells via its Fc fragment to exert the function of ADCC. The trifunctional antibody could transiently link immune effector cells to tumor cells and exhibited antitumor activity [35, 36] (Fig. 2a). MM-111 is a novel bispecific antibody, it specifically targets the HER2/HER3 heterodimer and blocks the binding of heregulin (HRG) and HER3, and then inhibits HER3 downstream signaling pathways [37] (Fig. 2b). Moreover, activated $\mathrm{T}$ cell armed with HER2-targeted bispecific

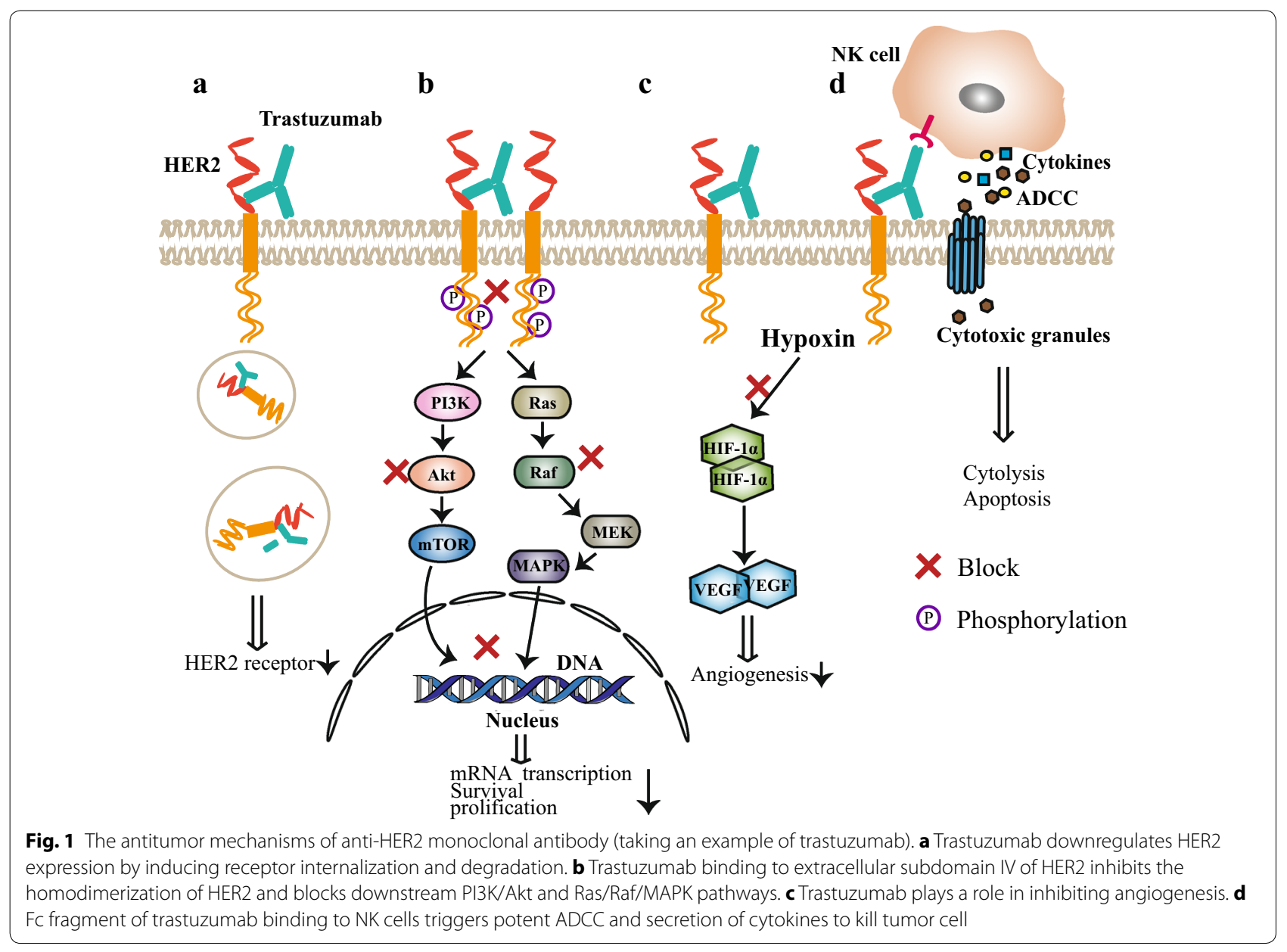




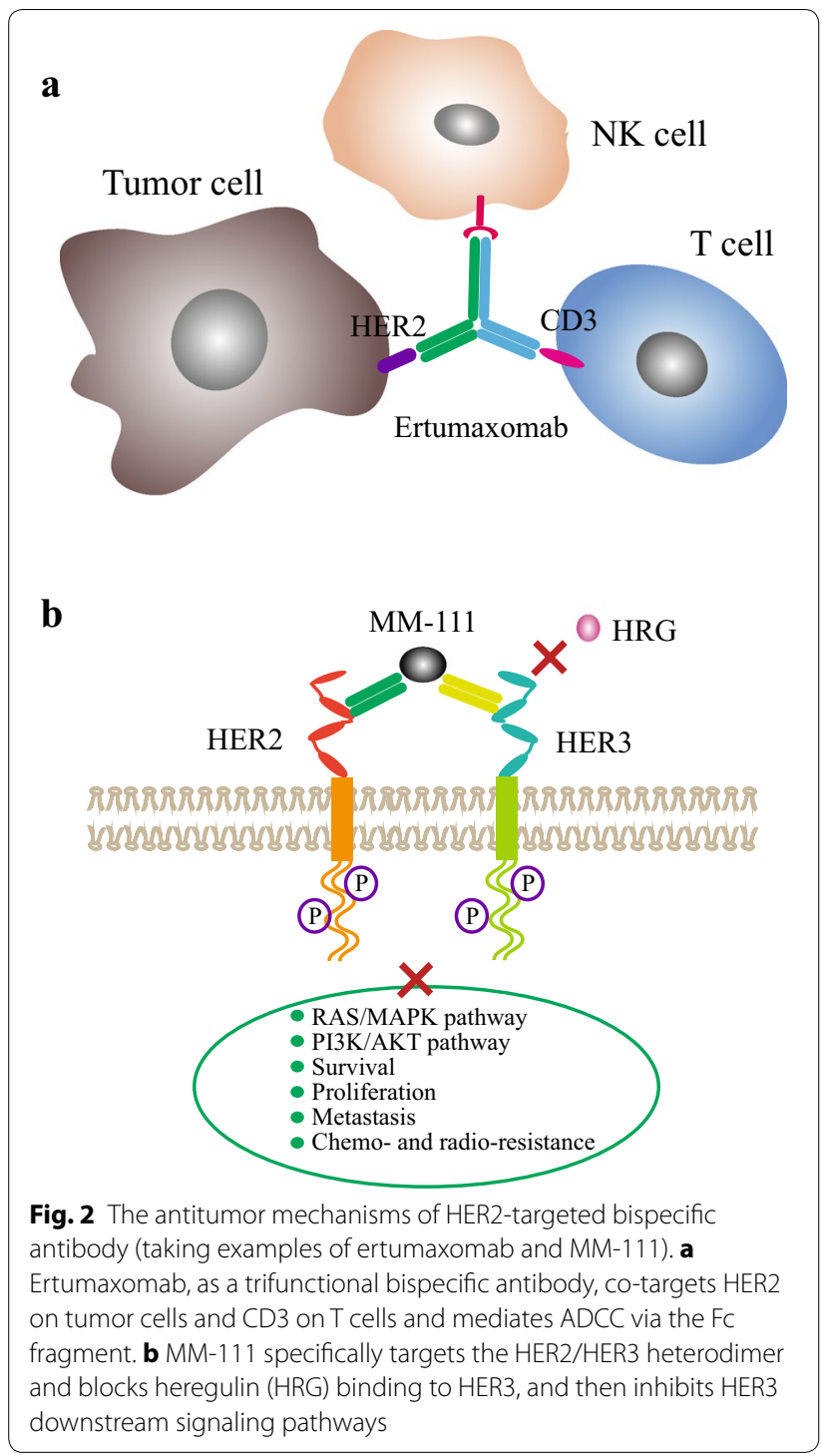

antibody (HER2Bi-aATC) exhibited significant inhibition in drug-resistant solid tumors [38]. In this review, we summarized the recent advancement of HER2-targeted monoclonal antibodies (trastuzumab, pertuzumab and T-DM1) and bispecific antibodies (MM-111, ertumaxomab and HER2Bi-aATC), especially focus on clinical trial results (completed and ongoing trials of anti-HER2 monoclonal antibodies in Tables 1 and 2, respectively, and clinical trials of HER2-targeted bispecific antibodies in Table 3).

\section{Clinical application of anti-HER2 monoclonal antibodies}

Trastuzumab (herceptin)

Trastuzumab is a recombined humanized monoclonal antibody which binds to the extracellular domain IV of
HER2 [39]. Trastuzumab is the first anti-HER2 antibody approved by Food and Drug Administration (FDA) in 1998 for the treatment of patients with HER2-overexpressed metastatic breast cancer [40]. Compared with chemotherapy alone, trastuzumab plus chemotherapy exhibited more effective outcomes and better tolerance in HER2-positive breast cancer [41-46]. The combination of aromatase inhibitors (letrozole, anastrozole) and trastuzumab was considered as a treatment option for patients with HER2 positive and hormone receptor positive metastatic breast cancer [47, 48]. 1 year of adjuvant trastuzumab was considered as standard treatment for patients with HER2-positive early breast cancer [49]. A clinical trial (NCT00045032) compared the 2 years of adjuvant trastuzumab versus 1 year of treatment demonstrating that the curative effects of 2 years' treatment was not more effective than of 1 year's treatment [50]. Another study did not show that 6 months of adjuvant trastuzumab was non-inferior to 12 months of treatment [51]. In patients with HER2-positive, trastuzumab-refractory metastatic breast cancer, lapatinib in combination with trastuzumab significantly improved progressionfree survival (PFS) and clinical benefit rate (CBR) versus lapatinib alone [31]. But the combination of lapatinib and trastuzumab as adjuvant treatment in early HER2positive breast cancer did not statistically significantly improve disease-free survival (DFS) compared with trastuzumab alone [52]. PAMELA study (NCT01973660) is an open-label, single-group, multicenter, phase 2 trial in patients with early-stage HER2-positive breast cancer treated with trastuzumab and lapatinib. At the time of surgery, 41 of 101 patients (41\%) with HER2-enriched subtypes and 5 of 50 patients (10\%) with non-HER2-positive subtypes achieved pathological complete response (pCR). The study suggested that HER2-enriched subtype could be supposed as a predictor of pCR before the dual HER2 blockade therapies [53]. The REMAGUS 02 trial compared the pCR, DFS and overall survival (OS) in patients with locally advanced breast cancer treated with neoadjuvant chemotherapy plus celecoxib or trastuzumab. In the HER2-positive population, the combinated application of neoadjuvant and trastuzumab significantly increased pCR rates but not associated with DFS and OS. But axillary pCR may be used as a surrogate predictor of DFS and OS. Patients with HER2-positive breast cancer achieved higher DFS and OS than patients with HER2negative breast cancer [54]. TRAIN study evaluated the efficacy and toxicity of weekly trastuzumab in combination with paclitaxel plus carboplatin as neoadjuvant treatment in patients with HER2-positive breast cancer. The pCR rate of 108 eligible patients in breast and axilla was $43 \%$ (95\% CI 33-52) and the 3 -year OS was $92 \%$ (95\% CI 88-98) [55]. Xavier et al. compared the sequential 
Table 1 Completed clinical trials of anti-HER2 monoclonal antibodies

\begin{tabular}{|c|c|c|c|c|c|c|}
\hline Drug & Identifier & Disease & Phase & Status & Treatment arms & Endpoints \\
\hline Trastuzumab & NCT01450696 (HELOISE) & HER2+ gastric cancer & 3 & Completed & $\begin{array}{l}\text { a. Capecitabine + cispl- } \\
\text { atin + trastuzumab } \\
(6 \mathrm{mg} / \mathrm{kg}) \\
\text { b. Capecitabine + cispl- } \\
\text { atin + trastuzumab } \\
(10 \mathrm{mg} / \mathrm{kg})\end{array}$ & $\begin{array}{l}\text { OS } \\
\text { a. } 12.5 \text { months } \\
\text { b. } 10.6 \text { months } \\
\text { C }_{\text {trough }} \text { increased in high } \\
\text { dose trastuzumab }\end{array}$ \\
\hline Trastuzumab & NCT01041404 (ToGA) & $\begin{array}{l}\text { HER2+ advanced gastric } \\
\text { cancer }\end{array}$ & 3 & Completed & $\begin{array}{l}\text { a. Trastuzumab + fluoro- } \\
\text { pyrimidine + cisplatin } \\
\text { b. Fluoropyrimidine + cis- } \\
\text { platin }\end{array}$ & $\begin{array}{l}\text { OS } \\
\text { a. } 13.8 \text { months } \\
\text { b. } 11.1 \text { months }\end{array}$ \\
\hline Pertuzumab & $\begin{array}{l}\text { NCT00545688 (Neo- } \\
\text { Sphere) }\end{array}$ & HER2+ breast cancer & 2 & Completed & $\begin{array}{l}\text { a. Trastuzumab + doc- } \\
\text { etaxel } \\
\text { b. Trastuzumab + doc- } \\
\text { etaxel + pertuzumab } \\
\text { c. Trastuzumab + pertu- } \\
\text { zumab } \\
\text { d. Pertuzumab + doc- } \\
\text { etaxel }\end{array}$ & $\begin{array}{l}\text { pCR } \\
\text { a. } 29.0 \% \\
\text { b. } 45.8 \% \\
\text { c. } 16.8 \% \\
\text { d. } 24.0 \% \\
\text { PFS } \\
\text { a. } 81 \% \\
\text { b. } 86 \% \\
\text { c. } 73 \% \\
\text { d. } 73 \% \\
\text { DFS } \\
\text { a. } 81 \% \\
\text { b. } 84 \% \\
\text { c. } 80 \% \\
\text { d. } 75 \%\end{array}$ \\
\hline Pertuzumab & $\begin{array}{l}\text { NCT00567190 } \\
\text { (CLEOPATRA) }\end{array}$ & $\begin{array}{l}\text { HER2+ metastatic breast } \\
\text { cancer }\end{array}$ & 3 & Completed & $\begin{array}{l}\text { a. Pertuzumab + trastu- } \\
\text { zumab + docetaxel } \\
\text { b. Placebo + trastu- } \\
\text { zumab + docetaxel }\end{array}$ & $\begin{array}{l}\text { OS } \\
\text { a. } 56.5 \text { months } \\
\text { b. } 40.8 \text { months } \\
\text { PFS } \\
\text { a. } 18.7 \text { months } \\
\text { b. } 12.4 \text { months }\end{array}$ \\
\hline Pertuzumab & $\begin{array}{l}\text { NCT00976989 (TRY- } \\
\text { PHAENA) }\end{array}$ & HER2+ breast cancer & 2 & Completed & $\begin{array}{l}\text { a. Pertuzumab + trastu- } \\
\text { zumab + FEC } \\
\text { b. Pertuzumab + tras- } \\
\text { tuzumab + doc- } \\
\text { etaxel + FEC } \\
\text { c. Pertuzumab + tras- } \\
\text { tuzumab + doc- } \\
\text { etaxel + carboplatin }\end{array}$ & $\begin{array}{l}\text { PCR } \\
\text { a. } 61.6 \% \\
\text { b. } 57.3 \% \\
\text { c. } 66.2 \% \\
\text { CCR } \\
\text { a. } 50.7 \% \\
\text { b. } 28.0 \% \\
\text { c. } 40.3 \%\end{array}$ \\
\hline $\begin{array}{l}\text { Pertuzumab } \\
\text { T-DM1 }\end{array}$ & NCT00951665 & $\begin{array}{l}\text { HER2 + locally advanced/ } \\
\text { metastatic breast cancer }\end{array}$ & $1 / 2$ & Completed & $\begin{array}{l}\text { a. T-DM1 } 3.6 \mathrm{mg} / \mathrm{kg} \\
(\mathrm{Q} 3 \mathrm{~W})+\text { paclitaxel } \\
80 \mathrm{mg} / \mathrm{m}^{2}(\mathrm{QW}) \\
\text { b. T-DM1 } 3.6 \mathrm{mg} / \mathrm{kg} \\
(\mathrm{Q} 3 \mathrm{~W})+\text { paclitaxel } \\
80 \mathrm{mg} / \mathrm{m}^{2}(\mathrm{QW})+\text { per- } \\
\text { tuzumab }(\mathrm{Q} 3 \mathrm{~W})\end{array}$ & $\begin{array}{l}\text { Total ORR: } 50.0 \% \\
\text { Total CBR: } 56.8 \% \\
\text { Total incidence of grade } 3 \\
\text { or worse AEs: } 77.3 \%\end{array}$ \\
\hline $\begin{array}{l}\text { Pertuzumab } \\
\text { T-DM1 }\end{array}$ & NCT00951665 & $\begin{array}{l}\text { HER2 + locally advanced/ } \\
\text { metastatic breast cancer }\end{array}$ & $1 / 2$ & Completed & $\begin{array}{l}\text { a. T-DM1 } 3.6 \mathrm{mg} / \mathrm{kg} \\
(\mathrm{Q} 3 \mathrm{~W})+\text { paclitaxel } \\
80 \mathrm{mg} / \mathrm{m}^{2}(\mathrm{QW}) \\
\text { b. T-DM1 } 3.6 \mathrm{mg} / \mathrm{kg} \\
(\mathrm{Q} 3 \mathrm{~W})+\text { paclitaxel } \\
80 \mathrm{mg} / \mathrm{m}^{2}(\mathrm{QW})+\text { per- } \\
\text { tuzumab }(\mathrm{Q} 3 \mathrm{~W})\end{array}$ & $\begin{array}{l}\text { Total ORR: } 50.0 \% \\
\text { Total CBR: } 56.8 \% \\
\text { Total incidence of grade } 3 \\
\text { or worse AEs: } 77.3 \%\end{array}$ \\
\hline T-DM1 & NCT01641939 (GATSBY) & $\begin{array}{l}\text { HER2 + advanced gastric } \\
\text { cancer }\end{array}$ & $2 / 3$ & Completed & $\begin{array}{l}\text { a. T-DM1 }(2.4 \mathrm{mg} / \mathrm{kg}) \\
\text { b. Standard taxane therapy }\end{array}$ & $\begin{array}{l}\text { Median follow-up } \\
\text { a. } 17.5 \text { months } \\
\text { b. } 15.4 \text { months } \\
\text { OS } \\
\text { a. } 7.9 \text { months } \\
\text { b. } 8.6 \text { months } \\
\text { Incidences of grade } 3 \text { or } \\
\text { more AEs } \\
\text { a. } 60 \% \\
\text { b. } 70 \%\end{array}$ \\
\hline
\end{tabular}


Table 1 continued

\begin{tabular}{|c|c|c|c|c|c|c|}
\hline Drug & Identifier & Disease & Phase & Status & Treatment arms & Endpoints \\
\hline T-DM1 & NCT01120184 (MARIANNE) & $\begin{array}{l}\text { HER2+ locally advanced/ } \\
\text { metastatic breast cancer }\end{array}$ & 3 & Completed & $\begin{array}{l}\text { a. Trastuzumab + taxane } \\
\text { b. T-DM1 + pertuzumab } \\
\text { c. T-DM1 + placebo }\end{array}$ & $\begin{array}{l}\text { Response rate } \\
\text { a. } 67.9 \% \\
\text { b. } 59.7 \% \\
\text { c. } 64.2 \% \\
\text { PFS } \\
\text { a. } 13.7 \text { months } \\
\text { b. } 14.1 \text { months } \\
\text { c. } 15.2 \text { months } \\
\text { Incidence of grade } 3 \text { or } \\
\text { worse AEs } \\
\text { a. } 54.1 \% \\
\text { b. } 45.4 \% \\
\text { c. } 46.2 \%\end{array}$ \\
\hline T-DM1 & NCT00829166 (EMILIA) & $\begin{array}{l}\text { HER2+ locally advanced/ } \\
\text { metastatic breast cancer }\end{array}$ & 3 & Completed & $\begin{array}{l}\text { a. T-DM1 } \\
\text { b. Capecitabine + lapat- } \\
\text { inib }\end{array}$ & $\begin{array}{l}\text { ORR } \\
\text { a. } 43.6 \% \\
\text { b. } 30.8 \% \\
\text { PFS } \\
\text { a. } 9.6 \text { months } \\
\text { b. } 6.4 \text { months } \\
\text { OS } \\
\text { a. } 30.9 \text { months } \\
\text { b. } 25.1 \text { months } \\
\text { Incidence of grade } 3 \text { or } \\
\text { worse AEs } \\
\text { a. } 57 \% \\
\text { b. } 41 \%\end{array}$ \\
\hline T-DM1 & NCT01419197 (TH3RESA) & HER2+ breast cancer & 3 & Completed & $\begin{array}{l}\text { a. T-DM1 } \\
\text { b. Treatment of physician's } \\
\text { choice }\end{array}$ & $\begin{array}{l}\text { OS } \\
\text { a. } 22.7 \text { months } \\
\text { b. } 15.8 \text { months } \\
\text { PFS } \\
\text { a. } 6.2 \text { months } \\
\text { b. } 3.3 \text { months } \\
\text { Incidence of grade } 3 \text { or } \\
\text { worse AEs } \\
\text { a. } 40 \% \\
\text { b. } 47 \%\end{array}$ \\
\hline MM-302 & NCT02213744 (HERMIONE) & $\begin{array}{l}\text { HER2 + locally advanced/ } \\
\text { metastatic breast cancer }\end{array}$ & $2 / 3$ & Completed & $\begin{array}{l}\text { a. MM-302 + trastuzumab } \\
\text { b. Chemotherapy of physi- } \\
\text { cian's choice + trastu- } \\
\text { zumab }\end{array}$ & $\begin{array}{l}\text { OS } \\
\text { a. } 13.8 \text { months } \\
\text { b. } 11.1 \text { months }\end{array}$ \\
\hline
\end{tabular}

The details of Table 1 derived from http://clinicaltrials.gov/

FEC, 5-fluorouracil, epirubicin, cyclophosphamide, CCR clinical complete response, Q3W every three weeks, QW every week, CBR clinical benefit, rateC trough trastuzumab serum trough concentration, ORR objective response rate

administration of trastuzumab after adjuvant chemotherapy with the concomitant administration of trastuzumab and adjuvant chemotherapy. They found that two regimens achieved similar DFS and OS [56]. Besides breast cancer, in HER2-positive advanced gastric or gastroesophageal cancer, trastuzumab plus chemotherapy contributed to longer median OS than chemotherapy alone (13.8 months vs 11.1 months) [5].

\section{Pertuzumab (perjeta)}

Like trastuzumab, pertuzumab is a HER2-targeted monoclonal antibody. However, pertuzumab binds to the extracellular subdomain II of HER2 and then inhibited dimerization with other HER receptors, including EGFR,
HER3 and HER4 [19]. Hence, pertuzumab has a complementary mode of action compared with trastuzumab. Pertuzumab was first studied in patients with HER2positive metastatic breast cancer whose disease had progressed during or after previous treatment including trastuzumab [57].

NeoSphere (NCT00545688) is a randomized multicenter, phase 2 study in patients with locally advanced, inflammatory, or early HER2-positive breast cancer. 417 eligible patients were randomly assigned to group A ( $\mathrm{n}=107$, regimen: trastuzumab + docetaxel), group $B(n=107$, regimen: pertuzumab + trastuzumab + docetaxel), group $C(n=107$; regimen: pertuzumab + trastuzumab), and group $\mathrm{D}(\mathrm{n}=96$; regimen: 
Table 2 Ongoing clinical trials of anti-HER2 monoclonal antibodies

\begin{tabular}{|c|c|c|c|c|}
\hline Drug & Identifier & Disease & Phase & Treatment arms \\
\hline Trastuzumab & NCT01367002 & HER2+ uterine serous cancer & 2 & $\begin{array}{l}\text { a. Carboplatin + paclitaxel + trastuzumab } \\
\text { b. Carboplatin + paclitaxel }\end{array}$ \\
\hline Trastuzumab & NCT01196390 & Esophageal cancer & 3 & $\begin{array}{l}\text { a. Radiation + chemotherapy + trastuzumab } \\
\text { b. Radiation + chemotherapy }\end{array}$ \\
\hline Trastuzumab & NCT01325207 & CNS progression HER2+ breast cancer & $1 / 2$ & Intravenous trastuzumab \\
\hline Trastuzumab & NCT02030561 & HER2+ breast and gastric cancer & $1 / 2$ & Trastuzumab + NK cells \\
\hline Trastuzumab & NCT02598310 & HER2 +/ER - operable breast cancer & 2 & Nab-paclitaxel + trastuzumab \\
\hline Trastuzumab & NCT01340430 & HER2+ breast cancer & 2 & FEC + paclitaxel + trastuzumab \\
\hline Trastuzumab & NCT01785420 & HER2 + operable breast cancer & 3 & $\begin{array}{l}\text { a. Trastuzumab } \\
\text { b. Placebo }\end{array}$ \\
\hline Trastuzumab & NCT02152943 & HR-/HER2+ advanced cancers & 1 & Everolimus + letrozole + trastuzumab \\
\hline Trastuzumab & NCT01950182 (SYSUCC-002) & Luminal B2 breast cancer & 3 & $\begin{array}{l}\text { a. Trastuzumab + chemotherapy } \\
\text { b. Endocrine therapy + trastuzumab }\end{array}$ \\
\hline Trastuzumab & NCT01873833 & HER2 + metastatic breast cancer & 2 & $\begin{array}{l}\text { Chemotherapy + lapatinib ditosylate }+ \text { tras- } \\
\text { tuzumab }\end{array}$ \\
\hline Pertuzumab & NCT01996267 (TRAIN-2) & HER2+ breast cancer & 3 & $\begin{array}{l}\text { a. FEC-T + pertuzumab } \\
\text { b. PTC + pertuzumab }\end{array}$ \\
\hline Pertuzumab & NCT01572038 (PERUSE) & HER2+ breast cancer & 3 & Pertuzumab + trastuzumab + taxane \\
\hline Pertuzumab & NCT02229149 & HER2 + metastatic breast cancer & 2 & $\begin{array}{l}\text { a. Chemotherapy + trastuzumab + pertu- } \\
\text { zumab } \\
\text { b. Chemotherapy + trastuzumab }\end{array}$ \\
\hline Pertuzumab & NCT02896855 & HER2 + metastatic breast cancer & 3 & $\begin{array}{l}\text { a. Pertuzumab + trastuzumab + docetaxel } \\
\text { b. Placebo + trastuzumab + docetaxel }\end{array}$ \\
\hline Pertuzumab & NCT02625441 & HER2+ early breast cancer & 3 & $\begin{array}{l}\text { a. Pertuzumab + trastuzumab + docetaxel } \\
\text { b. Trastuzumab + docetaxel }\end{array}$ \\
\hline $\begin{array}{l}\text { Trastuzumab } \\
\text { Pertuzumab }\end{array}$ & NCT02139358 & HER2+ metastatic breast cancer & $1 / 2$ & Gemcitabine + trastuzumab + pertuzumab \\
\hline $\begin{array}{l}\text { Trastuzumab } \\
\text { Pertuzumab }\end{array}$ & NCT01774786 & $\begin{array}{l}\text { HER2 + gastric or gastroesophageal junction } \\
\text { cancer }\end{array}$ & 3 & Pertuzumab + trastuzumab + chemotherapy \\
\hline $\begin{array}{l}\text { Trastuzumab } \\
\text { Pertuzumab }\end{array}$ & NCT02536339 & CNS progression HER2+ breast cancer & 2 & Pertuzumab + high-dose trastuzumab \\
\hline $\begin{array}{l}\text { Trastuzumab } \\
\text { Pertuzumab }\end{array}$ & NCT02598427 & CNS progression HER2+ breast cancer & 1 & Intrathecal + pertuzumab + trastuzumab \\
\hline $\begin{array}{l}\text { Trastuzumab } \\
\text { Pertuzumab }\end{array}$ & NCT02581462 & HER2 + gastric or gastroesophageal cancer & $2 / 3$ & $\begin{array}{l}\text { a. FLOT } \\
\text { b. FLOT + trastuzumab + pertuzumab }\end{array}$ \\
\hline $\begin{array}{l}\text { Trastuzumab } \\
\text { Pertuzumab }\end{array}$ & NCT02436993 & Breast cancer & 2 & $\begin{array}{l}\text { a. Carboplatin + paclitaxel + bevacizumab } \\
\text { (HER2-) } \\
\text { b. Carboplatin + paclitaxel + trastu- } \\
\text { zumab + pertuzumab (HER2 +) }\end{array}$ \\
\hline $\begin{array}{l}\text { Trastuzumab } \\
\text { Pertuzumab }\end{array}$ & NCT02411344 & HER2+/HR+ breast cancer & 2 & Pertuzumab + trastuzumab + letrozole \\
\hline $\begin{array}{l}\text { T-DM1 } \\
\text { Pertuzumab }\end{array}$ & NCT02326974 & HER2+ breast cancer & 2 & T-DM1 + pertuzumab \\
\hline T-DM1 & NCT02414646 & HER2+ breast cancer & 2 & T-DM1 \\
\hline T-DM1 & NCT02675829 & HER2 amplified or mutant cancers & 2 & T-DM1 \\
\hline T-DM1 & NCT01702571 & $\begin{array}{l}\text { HER2 + locally advanced/metastatic breast } \\
\text { cancer }\end{array}$ & 3 & T-DM1 \\
\hline T-DM1 & NCT02289833 & HER2 + locally advanced/metastatic NSCLC & 2 & T-DM1 \\
\hline T-DM1 & NCT01966471 & HER2+ primary breast cancer & 3 & $\begin{array}{l}\text { a. T-DM1 + pertuzumab } \\
\text { b. Trastuzumab + pertuzumab + taxane }\end{array}$ \\
\hline T-DM1 & NCT01772472 (KATHERINR) & HER2+ breast cancer & 3 & $\begin{array}{l}\text { a. T-DM1 } \\
\text { b. Trastuzumab }\end{array}$ \\
\hline MGAH22 & NCT01148849 & HER2+ cancers & 1 & MGAH22 (margetuximab) \\
\hline MGAH22 & NCT02492711 (SOPHIA) & HER2 + metastatic breast cancer & 3 & $\begin{array}{l}\text { a. Margetuximab + chemotherapy } \\
\text { b. Trastuzumab + chemotherapy }\end{array}$ \\
\hline
\end{tabular}


Table 2 continued

\begin{tabular}{|c|c|c|c|c|}
\hline Drug & Identifier & Disease & Phase & Treatment arms \\
\hline$\overline{M G A H 22}$ & NCT02689284 & $\begin{array}{l}\text { HER2+ gastric or gastroesophageal junction } \\
\text { cancer }\end{array}$ & $1 / 2$ & Margetuximab + pembrolizumab \\
\hline XMT-1522 & NCT02952729 & $\begin{array}{l}\text { HER2 + breast cancer, NSCLC and gastric } \\
\text { cancer }\end{array}$ & 1 & XMT-1522 \\
\hline DS-8201a & NCT02564900 & Advanced solid tumors & 1 & DS-8201a \\
\hline SYD985 & NCT02277717 & Locally advanced/metastatic solid tumors & 1 & SYD985 \\
\hline
\end{tabular}

The details of Table 2 derived from http://clinicaltrials.gov/

FLOT fluorouracil, leucovorin, oxaliplatin, docetaxel, FEC fluorouracil, epirubicin, cyclophosphamide, FEC-T fluorouracil, epirubicin, cyclophosphamide, trastuzumab, PTC paclitaxel, trastuzumab, carboplatin, CNS central nervous system, NSCLC non-small cell lung cancer

Table 3 Clinical trials of HER2-targeted bispecific antibodies

\begin{tabular}{|c|c|c|c|c|c|c|}
\hline Drug & Targets & Diseases & Treatment arms & Phase & Status & Identifier \\
\hline Ertumaxomab & HER2/CD3 & Metastatic breast cancer & Ertumaxomab & 2 & Terminated & NCT00452140 \\
\hline Ertumaxomab & HER2/CD3 & Metastatic breast cancer & Ertumaxomab & 2 & Terminated & NCT00522457 \\
\hline Ertumaxomab & HER2/CD3 & Her2+ advanced solid tumors & Ertumaxomab & $1 / 2$ & Terminated & NCT01569412 \\
\hline MM-111 & HER2/HER3 & $\begin{array}{l}\text { Her2+, heregulin+, breast } \\
\text { cancer }\end{array}$ & MM-111 & 1 & Completed & NCT00911898 \\
\hline MM-111 & HER2/HER3 & $\begin{array}{l}\text { Her2+, heregulin+, breast } \\
\text { cancer }\end{array}$ & MM-111 + trastuzumab & 1 & Completed & NCT01097460 \\
\hline MM-111 & HER2/HER3 & HER2 + solid tumors & $\begin{array}{l}\text { a. Cisplatin + capecita- } \\
\text { bin + trastu- } \\
\text { zumab + MM-111 } \\
\text { b. Lapatinib + trastu- } \\
\text { zumab + MM-111 } \\
\text { c. Paclitaxel + trastu- } \\
\text { zumab + MM-111 } \\
\text { d. Lapatinib + tras- } \\
\text { tuzumab + pacli- } \\
\text { taxel + MM-111 } \\
\text { e. Docetaxel + trastu- } \\
\text { zumab + MM-111 }\end{array}$ & 1 & Completed & NCT01304784 \\
\hline MM-111 & HER2/HER3 & $\begin{array}{l}\text { HER2+ esophagus cancer, } \\
\text { gastroesophageal junction } \\
\text { cancer, stomach cancer }\end{array}$ & $\begin{array}{l}\text { a. MM-111 + paclitaxel + tras- } \\
\text { tuzumab } \\
\text { b. Paclitaxel + trastuzumab }\end{array}$ & 2 & Completed & NCT01774851 \\
\hline HER2Bi-aATC & HER2/CD3 & $\begin{array}{l}\text { Her2+ neoplasms of digestive } \\
\text { system }\end{array}$ & Interleukin-2 + HER2Bi-aATC & 1 & Recruiting & NCT02662348 \\
\hline MCLA-128 & HER2/HER3 & $\begin{array}{l}\text { HER2 + malignant solid } \\
\text { tumors }\end{array}$ & $\begin{array}{l}\text { a. MCLA-128 dose escalation } \\
\text { b. MCLA-128 for breast cancer } \\
\text { c. MCLA-128 for ovarian } \\
\text { cancer } \\
\text { d. MCLA-128 for gastric/GE } \\
\text { junction cancer } \\
\text { e. MCLA-128 for endometrial } \\
\text { cancer } \\
\text { f. MCLA-128 for NSCLC }\end{array}$ & $1 / 2$ & Recruiting & NCT02912949 \\
\hline GBR1302 & HER2/CD3 & HER2 + solid tumors & GBR1302 & 1 & Recruiting & NCT02829372 \\
\hline ZW25 & Two different epitopes of HER2 & HER2+ solid tumors & ZW25 & 1 & Recruiting & NCT02892123 \\
\hline
\end{tabular}

The details of Table 3 derived from http://clinicaltrials.gov/

pertuzumab + docetaxel). The study results demonstrated that the pCR rate in group B (49 of 107 [45.8\%]) was higher than in group A (31 of 107 [29.0\%]), group C (18 of 107 [16.8\%]), and group D (23 of 96 [24.0\%]). During the treatment of all regimens, the most common adverse events (AEs) of grade 3 or worse were neutropenia, febrile neutropenia, and leucopenia. The incidence of AEs did not show obvious distinction among groups [58]. The secondary endpoints of NeoSpere study including 5-year progression-free survival (PFS) and DFS were 
reported by Luca et al. The results support the primary endpoint (pCR) and suggest that $\mathrm{pCR}$ could be an indicator of long-term outcome in early-stage HER2-positive breast cancer. Moreover, neoadjuvant pertuzumab plus trastuzumab and docetaxel did not lead to additional and long-term cardiotoxicity. Therefore, the combination of pertuzumab with trastuzumab and docetaxel is beneficial for the improvement of pCR [59]. Directed at NeoSpere study, Giampaolo et al. conducted biomarker analysis. Their results indicated that HER2 positively related with pCR rates and treatment interaction with regimen of pertuzumab, trastuzumab plus docetaxel. But serum transforming growth factor-alpha (TGF- $\alpha$ ) showed a negative correlation with $\mathrm{pCR}$ rates with pertuzumab plus trastuzumab [59]. Moreover, the analysis of immune modulation of pCR after neoadjuvant HER2-targeting therapies demonstrated that higher expression of PD1, MHC-II and STAT1 were linked with higher $\mathrm{pCR}$, but higher level of PDL1, MHC-I or IF-1 were associated with lower Pcr [60].

The CLEOPATRA study (NCT00567190) is another randomized, double-blind, placebo-controlled phase III trial combining pertuzumab with trastuzumab plus docetaxel in HER2-positive metastatic breast cancer patients [61]. The results of CLEOPATRA trial demonstrated that adding pertuzumab to trastuzumab and docetaxel in patients with HER2-positive metastatic breast cancer significantly prolonged the median OS to 56.5 months. The median OS of placebo group was 40.8 months [62]. The investigator-assessed PFS was 18.7 months in the pertuzumab group, and 12.4 months in the placebo group [63]. The health-related qualityof-life (HRQoL) analysis from CLEOPATRA showed that adding pertuzumab to trastuzumab plus docetaxel had no adverse impacts on overall HRQoL and may prolong the time to deterioration of breast cancer-specific symptoms [64]. The incidence of central nervous system (CNS) metastases as first site of disease progression in patients from CLEOPATRA was similar between arms. Median time to development of CNS metastases as first site of disease progression in pertuzumab arms was longer than placebo arms (15.0 months vs 11.9 months). Median OS was prolonged in pertuzumab arms compared with the placebo (34.4 months vs 26.3 months) [65]. A retrospective analysis of the CLEOPATRA study investigated the prognostic role of tumor-infiltrating lymphocytes (TILs) in advanced HER2-positive breast cancer treated with pertuzumab or placebo in addition to trastuzumab and docetaxel. The results demonstrated that the higher level of stromal TILs was significantly associated with longer OS but not PFS [66]. However, high HER2 protein, high HER2 and HER3 mRNA levels, wild-type PIK3CA, and low serum HER2 extracellular domain (sHER2) were obviously benefit for PFS [67].

In TRYPHAENA study (NCT00976989), 225 patients with HER2-positive breast cancer were recruited and randomized 1:1:1 to receive six neoadjuvant cycles $\mathrm{q} 3 \mathrm{w}$ (arm A: 5-fluorouracil, epirubicin, cyclophosphamide $[$ FEC $]+$ trastuzumab + pertuzumab $\times 3$ weeks $\rightarrow$ docetaxel + trastuzumab + pertuzumab $\times 3$ weeks; arm B: FEC $\times 3$ weeks $\rightarrow$ docetaxel + trastuzumab + pertuzumab $\times 3$ weeks; arm C: docetaxel + carboplatin + trastuzumab + pertuzumab $\times 6$ weeks). The patients of this study achieved considerable pCR rate in three arms (arm A: $61.6 \%$; arm B: $57.3 \%$; arm C: $66.2 \%)$. During treatment, 2 patients $(2.7 \%$; arm B) suffered symptomatic left ventricular systolic dysfunction (LVSD) and 11 patients (arm A: 5.6\%; arm B: 5.3\%; arm C: 3.9\%) had declines in LVEF of $\geq 10 \%$ points from baseline to $<50 \%$ [68]. Based on the TRYPHAENA trial, another study analyzed a panel of biomarkers including HER2, HER3, EGFR, phosphatase and tensin homolog (PTEN), and phosphatidylinositol-4,5-bisphosphate 3-kinase catalytic subunit alpha (PIK3CA) to evaluate the predictive value of these biomarkers. The results demonstrated that HER2 protein and mRNA expression level were corrected/ correlated with the pCR rate [69]. A study analyzed the incidence and management of diarrhea in patients with HER2-positive breast cancer during the treatment of pertuzumab-containing through synthesizing three trials including CLEOPATRA $(\mathrm{n}=804)$, NeoSpere $(\mathrm{n}=416)$ and TRYPHAENA $(\mathrm{n}=223)$. The diarrhea was common and manageable adverse event. Besides, diarrhea always occurred during the first treatment cycle of pertuzumab [70].

\section{Ado-trastuzumab emtansine (T-DM1)}

T-DM1 is an antibody-drug conjugate (ADC) targeting HER2 to be approved for the treatment of HER2-positive metastatic breast cancers. It is composed of trastuzumab linked by a stable linker to cytotoxic agent emtansine, an inhibitor of tubulin [71, 72]. DM1 is released in HER2positive breast cancer cells resulting in cell cycle arrest and apoptosis [73]. Besides, T-DM1 also has the ability of trastuzumab inhibiting HER2-mediated signal pathways [74]. Linker is an important element for T-DM1. The most common linker is valine-citrulline (VC). Study demonstrated that valine-alanine (VA) based antibodydrug conjugates with monomethyl auristatin $\mathrm{E}$ is a promising therapy for cancer [75].

A retrospective study analyzed the incidence and time to symptomatic brain progression and median OS in patients with HER2-positive advanced breast cancer treated with single T-DM1 [76]. The median time to brain progression in 16 patients with brain disease 
before T-DM1 treatment was 9.9 months. The median OS was 15.3 months. In 39 patients without known brain disease before T-DM1, 7 patients (17.9\%) developed symptomatic brain progression during treatment with T-DM1 and the time to brain progression was 7.5 months. The median OS was 12.4 months [76]. Studies indicated that T-DM1 combined with paclitaxel or pertuzumab obviously enhanced the antitumor activity [77]. A phase 1b/2a study (NCT00951665) evaluated the maximum tolerated dose (MTD) and feasibility of T-DM1 + paclitaxel \pm pertuzumab in HER2-positive locally advanced breast cancer and metastatic breast cancer. The MTD of combination regimen was T-DM1 $3.6 \mathrm{mg} / \mathrm{kg}$ every 3 weeks or $2.4 \mathrm{mg} / \mathrm{kg}$ weekly + paclitaxel $80 \mathrm{ma} / \mathrm{m}^{2}$ weekly \pm pertuzumab $840 \mathrm{mg}$ loading dose followed by $420 \mathrm{mg}$ every 3 weeks. The Most common severe AEs were neutropenia and peripheral neuropathy that may affect the continuous treatment [78]. EMILIA study (NCT00829166) recruited 991 patients with HER2-positive metastatic breast cancer that previously treated with trastuzumab and taxane. Enrolled patients were randomly assigned to T-DM1 $(\mathrm{n}=495)$ and capecitabine plus lapatinib (control; $n=496$ ). An interim analysis results showed that median PFS assessed by an independent review was 9.6 months with T-DM1 versus 6.4 months with lapatinib plus capecitabine. The objective response rate (ORR) was $43.6 \%$ with T-DM1 vs $30.8 \%$ with control [79]. A final description analysis indicated that the median OS of T-DM1 group was longer than control group (29.9 months vs 25.9 months). Serious AEs observed in T-DM1 included thrombocytopenia, increased aspartate aminotransferase levels and anemia. The incidence of grade 3 or worse AEs in T-DM1 was lower than in control capecitabine plus lapatinib (48\% vs 60\%) [80]. GATSBY (NCT01641939) was a randomized, phase $2 / 3$ global study assessing the safety and efficacy of T-DM1 versus taxane treatment in patients with HER2positive locally advanced gastric or gastro-esophageal junction cancer that progressed during or after first-line therapy. The results suggested that $2.4 \mathrm{mg} / \mathrm{kg}$ T-DM1 weekly was the appropriate dose for treatment. However, the T-DM1 group did not show any superiority in median OS compared with the taxane group (7.9 months vs 8.6 months). The incidence of grade 3 or worse AEs in the T-DM1 group was lower than the taxane $(60 \%$ vs 70\%) [81]. TH3RESA study (NCT01419197), a randomized open-label phase 3 trial, compared treatment of T-DM1 with treatment of physician's choice in patients with previously treated HER2-positive metastatic breast cancer. 602 patients were assigned to T-DM1 group $(\mathrm{n}=404)$ and physician's choice group $(\mathrm{n}=198)$. The PFS of T-DM1 group was longer than physician's choice group (6.2 months vs 3.3 months). The incidence of neutropenia, diarrhea, and febrile neutropenia was higher in physician's choice group than in T-DM1 group. However, thrombocytopenia in T-DM1 group was more common [82]. A final analysis showed that the OS in T-DM1 group was significantly longer than treatment of physician's choice (22.7 months; 95\% CI [19.4-27.5] vs 15.8 months; 95\% CI [13.5-18.7]). The incidence of grade 3 or worse AEs was 161 of 403 (40\%) patients in T-DM1and 87 of 184 (47\%) patients in physician's choice [83]. However, in MARIANNE study (NCT01120184), 1095 recruited patients with HER2-positive advanced breast cancer were randomly assigned to three groups including trastuzumab + taxane $(\mathrm{n}=365)$, T-DM1 + placebo $(\mathrm{n}=367)$, and T-DM1 + pertuzumab $(\mathrm{n}=363)$. The PFS of three groups did not show significant difference (trastuzumab + taxane: 13.7 months vs T-DM1 + placebo: 14.1 months vs T-DM1 + pertuzumab: 15.2 months). The response rate $(67.4 \%$ vs $59.7 \%$ vs $64.2 \%$ ) and the incidence of grade 3 or worse AEs ( $54.1 \%$ vs $45.4 \%$ vs $46.2 \%$ ) also had no statistical difference [84].

\section{Other anti-HER2 monoclonal antibodies}

Margetuximab is a Fc-modified anti-HER2 antibody which suppresses the growth of HER2-positive tumor cells and promotes ADCC [85]. A phase 1 study (NCT01148849) was conducted to evaluate MTD, safety and antitumor activity of margetuximab in patients with HER2-overexpressing carcinomas. 66 patients treated with margetuximab including 34 patients received regimen A (intravenous infusion at dose of $0.1-6.0 \mathrm{mg} / \mathrm{kg}$ for 3 of every 3 weeks) and 32 patients received regimen $B$ (intravenous infusion at dose of $10-18 \mathrm{mg} / \mathrm{kg}$ for once every 3 weeks). 7 of 60 (12\%) evaluable patients had partial responses, 31 (52\%) had stable disease, and 22 (37\%) had progress disease. The MTD was not reached for two regimens. The AEs were mild and manageable. Therefore, margetuximab was a promising single-agent therapy for patients with HER2-positive tumors [85]. 1E11 is an anti-HER2 humanized monoclonal antibody that binds to subdomain IV but distinct from the epitope targeted by trastuzumab. Hence, 1E11 in combination with trastuzumab enhanced the antitumor efficacy in the HER2overexpressing gastric cancer cell lines [86]. MM-302 is a HER2-targeted liposome encapsulating doxorubicin and single-chain anti-HER2 antibody. The antitumor mechanism of MM-302 is to delivery of doxorubicin and DNA damage [87]. The combination of MM-302 and trastuzumab showed synergistic inhibition for tumor growth in HER2 positive xenograft models of breast and gastric cancer [87]. Moreover, the combination regimen has been studied in clinical trial (NCT02213744) [88]. SYD985 is a novel antibody-drug conjugate composed of 
trastuzumab and a highly potent DNA-alkylating agent (duocarmycin) [89]. SYD985 induced potent antitumor effects in high HER2 expression (3+) or low expression $(2+, 1+)$ in vitro and in vivo, while T-DM1 only showed high antitumor activity in HER2 3+ tumor cell lines and patient-derived xenograft (PDX) models. This phenomenon has been observed in HER2 positive uterine and ovarian carcinosarcoma [90], epithelial ovarian carcinoma [91], uterine serous carcinoma [92] and breast cancer [93]. DS-8201a contains an anti-HER2 antibody and a potent topoisomerase I inhibitor, exatecan derivative (DX-8951 derivative, DXd). DS-8201a exhibited significant bystander effect due to high drug-to-antibody ratio (DAR) [94]. For the T-DM1-resistant cells (N87-TDMR), DS-8201a remained inhibition for the tumor growth in vitro and in vivo [95]. XMT-1522, another novel ADC, is being studied in preclinical experiment and clinical trials (NCT02952729) [96].

\section{Preclinical and clinical studies of anti-HER2 bispecific antibodies \\ Ertumaxomab}

Ertumaxomab, as a trifunctional antibody, eliminates tumor cell lines regardless of HER2 expression level [97]. The ertumaxomab binding epitope on the extracellular of HER2 is different from trastuzumab and pertuzumab. In addition, the antitumor effects of ertumaxomab are mainly depends on the immune-mediated mechanisms. Therefore, for the patients with tumor of low HER2 expression or high HER2 expression but trastuzumabrefractory, ertumaxomab may be a promising therapeutic approach [98]. The trifunctional antibodies induced efficient killing of tumor cells via activating immune effector cells from patients that have received standard chemotherapy and radiotherapy [99].

A phase I clinical trial was conducted to estimate the safety and efficacy of ertumaxomab in patients with metastatic breast cancer. 15 of 17 enrolled patients completed the study with three ascending doses of ertumaxomab $(10-200 \mu \mathrm{g}) .100 \mu \mathrm{g} / \mathrm{kg}$ was suggested as the MTD. Severe side-effects including hypotension, respiratory distress syndrome, systemic inflammatory response syndrome, acute renal failure and heart failure were observed in the patients that infused with high doses (150 and $200 \mu \mathrm{g} / \mathrm{kg}$ ) ertumaxomab. There were 5 of 15 evaluable patients exhibited antitumor activity (one with complete response, two with partial response and two with stable disease). Besides, cytokines (IL-6, IL-2, TNF- $\alpha$ and IFN$\gamma)$ increased in peripheral blood and human anti-mouse/ anti-rat antibody was detected in 5 out of 16 evaluable patients [100]. 14 patients with HER2 expressing solid tumors (e.g. breast, gastric, rectal cancer) progressing after standard therapy were enrolled in a phase I clinical trial. Patients were divided into four cohorts and treated with signal ertumaxomab in a weekly escalating dosing regimen. The study results showed that single dose up to $300 \mu \mathrm{g}$ were well tolerated. Dose limiting toxicity was not detected and the MTD was not reached. All patients experienced treatment-related toxicities. But all AEs were mild and completely reversible. The clinical response to ertumaxomab was observed in 3 of 11 evaluable patients, including one partial remission and two disease stabilizations [101].

\section{MM-111}

MM-111, a novel bispecific antibody consisting of human anti-HER2 and anti-HER3 scFv linked by modified human serum albumin (HSA). HER2 has no known ligands and forms dimerization with other HER members. Ligand-activated HER3 preferentially binds HER2 [102]. HER2 and HER3 play a vital role in transcriptional regulation, proliferation, metastasis and chemo- and radio-resistance [103]. MM-111 simultaneously binding to HER2 and HER3 formed a trimeric inhibitory complex which blocked HER3 and PI3K pathway in the HER2overexpressing cancers. The combination of MM-111 and trastuzumab or lapatinib potently inhibited growth of HER2-overexpressing tumors in vivo and in vitro [104]. The binding of HER3 and HRG induced HER2:HER3 heterodimer signaling and resistance to trastuzumab in preclinical models [105].

A study demonstrated that HRG reduced the activity of trastuzumab and paclitaxel, but MM-111 remained activity in the presence of HRG in gastric cancer cells. The combination of MM-111, trastuzumab and paclitaxel may be a promising therapy for the patients with HER2 positive gastric cancer [106]. MM-111 and paclitaxel with trastuzumab has been entered into a clinical trial (NCT01774851) in patients with HER2 positive carcinomas of the distal esophagus, gastroesophageal junction and stomach. Besides, treatment with trastuzumab, lapatinib, and MM-111 may be a potent therapeutic approach for the patients with HER2 positive breast cancer [107]. In trastuzumab resistant cells, phosphorylation of EGFR, ERK, CREB, c-Jun, and AFT-1 significantly increased and HER ligands obviously raised at mRNA level. MM-111 and EGFR inhibitors inhibited the growth of trastuzumab resistant cells. Therefore, MM-111 combinates with EGFR inhibitors may be an effective therapeutic regimen for trastuzumab-resistant cancer [108]. MM-111 as a monotherapy or in combination with other HER2targeted treatment or chemotherapy for HER2 positive cancers was evaluated in serval phase 1 clinical studies (NCT00911898, NCT01097460, NCT01304784). 


\section{HER2Bi-aATCs}

HER2Bi-aATCs were generated from human peripheral blood mononuclear cells (PBMC) activated with anti-CD3 monoclonal antibody and interleukin 2 for 14 days and armed with anti-CD3 $\times$ anti-Her2 bispecific antibody. In vitro, HER2Bi-aATCs maintained the HER2Bi on the surface and cytotoxic activity as well as the secretion of cytokines and chemokines. PBMC isolated from patients that completed HER2Bi-aATCs infusion showed potent cytolytic activity against breast cancer cell line (SK-BR-3) [109]. Thakur et al. developed an in vitro model which contained naive PBMC, breast cancer cells (SK-BR-3), HER2Bi-aATCs and CpG oligonucleotides (ODNs). In this model, HER2Bi-aATCs targeting and killing tumor cells induced specific antitumor antibody responses [110]. HER2Bi-aATCs exhibited significant cytotoxic activity against HER2 positive colorectal carcinoma cells in vitro. In SCID-Beige mouse model, HER2Bi-aATCs also obviously inhibited the growth of Colo205-luc cells. Compared with unarmed ATCs, HER2Bi-aATCs expressed higher level of activation marker CD69 and secreted more IFN- $\gamma$ [111]. Amazingly, in HER2 positive melanoma, the same antitumor effects were observed in vivo and in vitro [112]. HER2Bi-aATCs improved the specific cytotoxicity toward PC3 prostate adenocarcinoma cells and increased the secretion of Th1 cytokines (GM-CSF, TNF- $\alpha$, IFN- $\gamma$ ) compared with unarmed ATCs. In PC3 xenografts, HER2Bi-aATCs also significantly inhibited tumor growth [38]. Due to most glioblastoma simultaneously express EGFR and HER2, bispecific antibody targeting EGFR and HER2 may be an effective strategy for the treatment of glioblastoma. HER2Bi- or EGFRBi-aATCs significantly killed $50-80 \%$ primary glioblastoma lines and a temozolomide-resistant variant of U251. Moreover, the increased secretion of Th1 cytokines (IFN- $\gamma$, GM-CSF and TNF- $\alpha$ ) and Th2 cytokine (IL-13) had been detected [113].

Eight metastatic castrate resistant prostate cancer (CRPC) patients were enrolled into a phase I dose escalation study. 7 of 8 patients were treated with two infusions of HER2Bi-aATCs per week for 4 weeks. Patients who received 40 and $80 \times 10^{9} \mathrm{HER} 2 \mathrm{Bi}$-aATCs doses exhibited 1 partial and 2 minor responses. The prostate specific antigen (PSA) levels significantly decreased in 3 of 7 patients, and the level of IFN- $\gamma$ and Th1 serum cytokines of two patients had increased. In addition, there were no dose limiting toxicities [114]. Another phase I clinical trial was conducted to determine the safety and efficacy of HER2Bi-aATCs in combination with IL-2 and GM-CSF in 23 patients with advanced breast cancer after enrollment of 14.5 weeks, 13 of 22 (59.1\%) evaluable patients achieved a stable disease condition and 9 of $22(40.9 \%)$ had progressive disease. The median OS for all patients was 36.2 months (57.4 months for the HER2 $3+$ group, 27.4 months for the HER2 0-2+ group). There were no dose limiting toxicities and the MTD was not reached. Encouragingly, HER2Bi-aATCs induced endogenous cytotoxicity and cytokine responses in patients with metastatic breast cancer [115].

\section{Other anti-HER2 bispecific antibodies}

MCLA-128 is a full length IGg1 bispecific antibody targeting HER2 and HER3 [116]. A phase 1/2 dose escalation clinical trial (NCT02912949) to evaluate the safety, tolerability and antitumor activity pf MCLA-128 in patients with solid tumors is ongoing [117]. GBR1302 is a targeting HER2 and CD3 bispecific antibody that has been entered a clinical study (NCT02829372) [118]. ZW25 is a novel humanized bispecific antibody directed against two distinct epitopes of HER2. In high and low HER2 expression, ZW25 showed potent antitumor activity in HER2 positive cancers. A trial (NCT02892123) of ZW25 in patients with advanced HER2-expressing cancers is recruiting patients [119]. Another bispecific antibody MDX-210 co-targeting HER2 and FcyRI, increased the efficacy in vitro when combined with granulocytecolony stimulating factor (G-CSF) in breast cancer patients overexpressing HER2 [120]. Negrin et al. investigated the ability of ani-HER2 $\mathrm{x}$ cancer antigen-125 (CA125) with cytokine-induced killer (CIK) cells against primary ovarian carcinomas. The results suggested that the cytolytic activity of CIK cells with BsAb was significantly higher than CIK cells alone [121]. Due to $12 \%$ primary breast cancer expressed both HER2 and CEA, the bispecific antibody simultaneously targeting HER2 and CEA on the same cell obviously enhanced tumor localization [122].

\section{Conclusions}

Trastuzumab has been regarded as a classical drug for the treatment of HER2 positive advanced cancers and showed stronger antitumor efficacy when combined with pertuzumab. The combined use of pertuzumab, trastuzumab and paclitaxel are regarded as standard treatment regimens for patients with HER2 positive metastatic breast cancer. However, drug-resistance to trastuzumab is a key limit factor. HER2-targeted bispecific antibodies including MM-111, ertumaxomab and HER2Bi-aATCs have exhibited significant efficiency for the HER2 positive drug-resistant malignant tumors in preclinical studies. Phase 1 or phase 2 clinical studies demonstrated that bispecific antibodies were safe and feasible for the treatment of HER2 positive cancers. But more studies are required to evaluate the effectiveness of bispecific antibodies. Synergetic application of drugs with different antitumor mechanisms may bring more benefit. Taken 
together, HER2-targeted immunotherapy including monoclonal antibody and bispecific antibody plays a crucial role in the treatment of HER2 positive cancers.

\begin{abstract}
Abbreviations
HER2: human epithelial growth factor receptor 2; PI3K: phosphoinositide 3-kinase; Akt: protein kinase B; mTOR: mammalian target of rapamycin; MAPK: mitogen-activated protein kinase; ADCC: antibody-dependent cell-mediated cytotoxicity; T-DM1: ado-trastuzumab emtansine; HRG: heregulin; HER2BiaATC: HER2-targeted bispecific antibody armed activated T cell; FDA: Food and Drug Administration; PFS: progression-free survival; CBR: clinical benefit rate; DFS: disease-free survival; pCR: pathological complete response; OS: overall survival; LEVF: left ventricular ejection fraction; AEs: adverse events; PFS: progression-free survival; TGFa: transforming growth factor alpha; HRQOL: health-related quality-of-life; CNS: central nervous system; TILs: tumor-infiltrating lymphocytes; sHER2: serum HER2 extracellular domain; FEC: 5-fluorouracil, epirubicin, cyclophosphamide; LVSD: left ventricular systolic dysfunction; PTEN: phosphatase and tensin homolog; PIK3CA: phosphatidylinositol-4,5-bisphosphate 3-kinase catalytic subunit alpha; ADC: antibody-drug conjugate; VC: valine-citrulline; VA: valine-alanine; MTD: maximum tolerated dose; ORR: objective response rate; PDX: patient-derived xenograft; DAR: drug-to-antibody ratio; HSA: human serum albumin; PBMC: peripheral blood mononuclear cells; ODNs: oligonucleotides; CRPC: castrate resistant prostate cancer; PSA: prostate specific antigen; G-CSF: granulocyte-colony stimulating factor; CA125: cancer antigen-125; CIK: cytokine-induced killer.
\end{abstract}

\section{Authors' contributions}

SY performed the selection of literature, drafted the manuscript and prepared the figures. QL, XH, WZ, and SQ collected the related references. KW and AL carried out the design of this review and revised the manuscript. All authors contributed to this manuscript. All authors read and approved the final manuscript.

\section{Acknowledgements}

Not applicable.

\section{Competing interests}

The authors declare that they have no competing interests.

\section{Availability of data and materials}

Data sharing not applicable to this article as no datasets were gener-

ated or analysed during the current study.

\section{Consent for publication}

Not applicable.

\section{Ethics approval and consent to participate}

Not applicable.

\section{Funding}

This review was supported by National Natural Science Foundation of China (Grant No. 81572608), Wuhan Science and Technology Bureau No. 2017060201010170 (KW), and the National High Technology Research and Development Program of China (No. 2015AA020301).

\section{Publisher's Note}

Springer Nature remains neutral with regard to jurisdictional claims in published maps and institutional affiliations.

Received: 23 October 2017 Accepted: 20 November 2017 Published online: 28 November 2017
References

1. Cho HS, Mason K, Ramyar KX, Stanley AM, Gabelli SB, Denney DW Jr, et al. Structure of the extracellular region of HER2 alone and in complex with the Herceptin Fab. Nature. 2003;421 (6924):756-60.

2. Jiang J, Dong L, Wang L, Wang L, Zhang J, Chen F, et al. HER2-targeted antibody drug conjugates for ovarian cancer therapy. Eur J Pharm Sci. 2016:93:274-86

3. Yan M, Parker BA, Schwab R, Kurzrock R. HER2 aberrations in cancer: implications for therapy. Cancer Treat Rev. 2014;40(6):770-80.

4. Owens MA, Horten BC, Da Silva MM. HER2 amplification ratios by fluorescence in situ hybridization and correlation with immunohistochemistry in a cohort of 6556 breast cancer tissues. Clin Breast Cancer. 2004;5(1):63-9.

5. Bang YJ, Van Cutsem E, Feyereislova A, Chung HC, Shen L, Sawaki $A$, et al. Trastuzumab in combination with chemotherapy versus chemotherapy alone for treatment of HER2-positive advanced gastric or gastro-oesophageal junction cancer (ToGA): a phase 3, open-label, randomised controlled trial. Lancet. 2010;376(9742):687-97.

6. Lae M, Couturier J, Oudard S, Radvanyi F, Beuzeboc P, Vieillefond A. Assessing HER2 gene amplification as a potential target for therapy in invasive urothelial bladder cancer with a standardized methodology: results in 1005 patients. Ann Oncol. 2010;21(4):815-9.

7. Chavez-Blanco A, Perez-Sanchez V, Gonzalez-Fierro A, Vela-Chavez T, Candelaria M, Cetina L, et al. HER2 expression in cervical cancer as a potential therapeutic target. BMC Cancer. 2004;4:59.

8. Javle M, Churi C, Kang HC, Shroff R, Janku F, Surapaneni R, et al. HER2/neu-directed therapy for biliary tract cancer. J Hematol Oncol. 2015;8:58.

9. Morrison C, Zanagnolo V, Ramirez N, Cohn DE, Kelbick N, Copeland $L$, et al. HER- 2 is an independent prognostic factor in endometrial cancer: association with outcome in a large cohort of surgically staged patients. J Clin Oncol. 2006;24(15):2376-85.

10. Lin WL, Kuo WH, Chen FL, Lee MY, Ruan A, Tyan YS, et al. Identification of the coexisting HER2 gene amplification and novel mutations in the HER2 protein-overexpressed mucinous epithelial ovarian cancer. Ann Surg Oncol. 2011;18(8):2388-94.

11. Nardi V, Sadow PM, Juric D, Zhao D, Cosper AK, Bergethon K, et al. Detection of novel actionable genetic changes in salivary duct carcinoma helps direct patient treatment. Clin Cancer Res. 2013;19(2):480-90.

12. Leong SM, Tan KM, Chua HW, Tan D, Fareda D, Osmany S, et al. Sampling circulating tumor cells for clinical benefits: how frequent? J Hematol Oncol. 2015;8:75.

13. Yu S, Li A, Liu Q, LiT, Yuan X, Han X, et al. Chimeric antigen receptor T cells: a novel therapy for solid tumors. J Hematol Oncol. 2017;10(1):78.

14. Yu S, Li A, Liu Q, Yuan X, Xu H, Jiao D, et al. Recent advances of bispecific antibodies in solid tumors. J Hematol Oncol. 2017;10(1):155.

15. Huang G, Chantry A, Epstein RJ. Overexpression of ErbB2 impairs ligand-dependent downregulation of epidermal growth factor receptors via a post-transcriptional mechanism. J Cell Biochem. 1999;74(1):23-30

16. Tzahar E, Waterman H, Chen X, Levkowitz G, Karunagaran D, Lavi S, et al. A hierarchical network of interreceptor interactions determines signal transduction by Neu differentiation factor/neuregulin and epidermal growth factor. Mol Cell Biol. 1996;16(10):5276-87.

17. Incorvati JA, Shah S, Mu Y, Lu J. Targeted therapy for HER2 positive breast cancer. J Hematol Oncol. 2013;6:38.

18. Hudis CA. Trastuzumab-mechanism of action and use in clinical practice. N Engl J Med. 2007;357(1):39-51.

19. Franklin MC, Carey KD, Vajdos FF, Leahy DJ, de Vos AM, Sliwkowski MX Insights into ErbB signaling from the structure of the ErbB2-pertuzumab complex. Cancer Cell. 2004;5(4):317-28.

20. Slamon DJ, Clark GM, Wong SG, Levin WJ, Ullrich A, McGuire WL. Human breast cancer: correlation of relapse and survival with amplification of the HER-2/neu oncogene. Science. 1987;235(4785):177-82.

21. Sukawa Y, Yamamoto H, Nosho K, Ito M, Igarashi H, Naito T, et al. HER2 expression and PI3K-Akt pathway alterations in gastric cancer. Digestion. 2014:89(1):12-7.

22. Petit AM, Rak J, Hung MC, Rockwell P, Goldstein N, Fendly B, et al. Neutralizing antibodies against epidermal growth factor and ErbB-2/neu receptor tyrosine kinases down-regulate vascular endothelial growth 
factor production by tumor cells in vitro and in vivo: angiogenic implications for signal transduction therapy of solid tumors. Am J Pathol. 1997;151(6):1523-30.

23. Holmes K, Roberts OL, Thomas AM, Cross MJ. Vascular endothelial growth factor receptor-2: structure, function, intracellular signalling and therapeutic inhibition. Cell Signal. 2007;19(10):2003-12.

24. Wainberg ZA, Anghel A, Desai AJ, Ayala R, Luo T, Safran B, et al. Lapatinib, a dual EGFR and HER2 kinase inhibitor, selectively inhibits HER2-amplified human gastric cancer cells and is synergistic with trastuzumab in vitro and in vivo. Clin Cancer Res. 2010;16(5):1509-19.

25. Chakraborty AK, Zerillo C, DiGiovanna MP. In vitro and in vivo studies of the combination of IGF1R inhibitor figitumumab (CP-751,871) with HER2 inhibitors trastuzumab and neratinib. Breast Cancer Res Treat. 2015;152(3):533-44

26. Valabrega G, Montemurro F, Sarotto I, Petrelli A, Rubini P, Tacchetti C, et al. TGFalpha expression impairs trastuzumab-induced HER2 downregulation. Oncogene. 2005;24(18):3002-10.

27. Liu J, Pan C, Guo L, Wu M, Guo J, Peng S, et al. A new mechanism of trastuzumab resistance in gastric cancer: MACC1 promotes the Warburg effect via activation of the PI3K/AKT signaling pathway. J Hematol Oncol. 2016;9(1):76.

28. Garcia-Saenz JA, Martin M, Puente J, Lopez-Tarruella S, Casado A, Moreno F, et al. Trastuzumab associated with successive cytotoxic therapies beyond disease progression in metastatic breast cancer. Clin Breast Cancer. 2005;6(4):325-9.

29. Hamberg P, Bos MM, Braun HJ, Stouthard JM, van Deijk GA, Erdkamp $F L$, et al. Randomized phase II study comparing efficacy and safety of combination-therapy trastuzumab and docetaxel vs. sequential therapy of trastuzumab followed by docetaxel alone at progression as first-line chemotherapy in patients with HER2 + metastatic breast cancer: HERTAX trial. Clin Breast Cancer. 2011;11(2):103-13.

30. Baselga J, Bradbury I, Eidtmann H, Di Cosimo S, de Azambuja E, Aura C, et al. Lapatinib with trastuzumab for HER2-positive early breast cancer (NeoALTTO): a randomised, open-label, multicentre, phase 3 trial. Lancet. 2012;379(9816):633-40.

31. Blackwell KL, Burstein HJ, Storniolo AM, Rugo H, Sledge G, Koehler M, et al. Randomized study of lapatinib alone or in combination with trastuzumab in women with ErbB2-positive, trastuzumab-refractory metastatic breast cancer. J Clin Oncol. 2010;28(7):1124-30.

32. Fu $W$, Wang $Y$, Zhang $Y$, Xiong $L$, Takeda $H$, Ding $L$, et al. Insights into HER2 signaling from step-by-step optimization of anti-HER2 antibodies. MAbs. 2014;6(4):978-90

33. Wu J, Fu J, Zhang M, Liu D. Blinatumomab: a bispecific T cell engager (BiTE) antibody against CD19/CD3 for refractory acute lymphoid leukemia. J Hematol Oncol. 2015;8:104.

34. Zhang $X$, Yang $Y$, Fan D, Xiong D. The development of bispecific antibodies and their applications in tumor immune escape. Exp Hematol Oncol. 2017;6:12.

35. Kiewe P, Thiel E. Ertumaxomab: a trifunctional antibody for breast cancer treatment. Expert Opin Investig Drugs. 2008;17(10):1553-8.

36. Fan G, Wang Z, Hao M, Li J. Bispecific antibodies and their applications. J Hematol Oncol. 2015;8:130.

37. Huhalov A, Adams S, Paragas V, Oyama S, Overland R, Luus L, et al. Abstract 3485: MM-111, an ErbB2/ErbB3 bispecific antibody with potent activity in ErbB2-overexpressing cells, positively combines with trastuzumab to inhibit growth of breast cancer cells driven by the ErbB2/ErbB3 oncogenic unit. Can Res. 2010;70(8 Supplement):3485.

38. Davol PA, Smith JA, Kouttab N, Elfenbein GJ, Lum LG. Anti-CD3 x antiHER2 bispecific antibody effectively redirects armed T cells to inhibit tumor development and growth in hormone-refractory prostate cancer-bearing severe combined immunodeficient beige mice. Clin Prostate Cancer. 2004;3(2):112-21.

39. Molina MA, Codony-Servat J, Albanell J, Rojo F, Arribas J, Baselga J. Trastuzumab (herceptin), a humanized anti-Her2 receptor monoclonal antibody, inhibits basal and activated Her2 ectodomain cleavage in breast cancer cells. Cancer Res. 2001;61 (12):4744-9.

40. Albanell J, Baselga J. Trastuzumab, a humanized anti-HER2 monoclonal antibody, for the treatment of breast cancer. Drugs Today. 1999;35(12):931-46.
41. Untch M, Rezai M, Loibl S, Fasching PA, Huober J, Tesch H, et al. Neoadjuvant treatment with trastuzumab in HER2-positive breast cancer: results from the GeparQuattro study. J Clin Oncol. 2010;28(12):2024-31.

42. Slamon DJ, Leyland-Jones B, Shak S, Fuchs H, Paton V, Bajamonde A, et al. Use of chemotherapy plus a monoclonal antibody against HER2 for metastatic breast cancer that overexpresses HER2. N Engl J Med. 2001;344(11):783-92.

43. Perez EA, Romond EH, Suman VJ, Jeong JH, Sledge G, Geyer CE Jr, et al. Trastuzumab plus adjuvant chemotherapy for human epidermal growth factor receptor 2-positive breast cancer: planned joint analysis of overall survival from NSABP B-31 and NCCTG N9831. J Clin Oncol. 2014;32(33):3744-52.

44. Gasparini G, Gion M, Mariani L, Papaldo P, Crivellari D, Filippelli G, et al. Randomized phase II trial of weekly paclitaxel alone versus trastuzumab plus weekly paclitaxel as first-line therapy of patients with Her-2 positive advanced breast cancer. Breast Cancer Res Treat. 2007;101(3):355-65.

45. Marty M, Cognetti F, Maraninchi D, Snyder R, Mauriac L, Tubiana-Hulin $M$, et al. Randomized phase II trial of the efficacy and safety of trastuzumab combined with docetaxel in patients with human epidermal growth factor receptor 2-positive metastatic breast cancer administered as first-line treatment: the M77001 study group. J Clin Oncol. 2005;23(19):4265-74.

46. Untch M, Fasching PA, Konecny GE, Hasmuller S, Lebeau A, Kreienberg $R$, et al. Pathologic complete response after neoadjuvant chemotherapy plus trastuzumab predicts favorable survival in human epidermal growth factor receptor 2-overexpressing breast cancer: results from the TECHNO trial of the AGO and GBG study groups. J Clin Oncol. 2011:29(25):3351-7.

47. Huober J, Fasching PA, Barsoum M, Petruzelka L, Wallwiener D, Thomssen C, et al. Higher efficacy of letrozole in combination with trastuzumab compared to letrozole monotherapy as first-line treatment in patients with HER2-positive, hormone-receptor-positive metastatic breast cancer-results of the eLEcTRA trial. Breast. 2012;21(1):27-33.

48. Kaufman B, Mackey JR, Clemens MR, Bapsy PP, Vaid A, Wardley A, et al. Trastuzumab plus anastrozole versus anastrozole alone for the treatment of postmenopausal women with human epidermal growth factor receptor 2-positive, hormone receptor-positive metastatic breast cancer: results from the randomized phase III TAnDEM study. J Clin Oncol. 2009;27(33):5529-37.

49. Slamon D, Eiermann W, Robert N, Pienkowski T, Martin M, Press M, et al. Adjuvant trastuzumab in HER2-positive breast cancer. N Engl J Med. 2011;365(14):1273-83.

50. Goldhirsch A, Gelber RD, Piccart-Gebhart MJ, de Azambuja E, Procter M, Suter TM, et al. 2 years versus 1 year of adjuvant trastuzumab for HER2positive breast cancer (HERA): an open-label, randomised controlled trial. Lancet. 2013;382(9897):1021-8.

51. Pivot X, Romieu G, Debled M, Pierga JY, Kerbrat P, Bachelot T, et al. 6 months versus 12 months of adjuvant trastuzumab for patients with HER2-positive early breast cancer (PHARE): a randomised phase 3 trial. Lancet Oncol. 2013;14(8):741-8.

52. Piccart-Gebhart M, Holmes E, Baselga J, de Azambuja E, Dueck AC, Viale $\mathrm{G}$, et al. Adjuvant lapatinib and trastuzumab for early human epidermal growth factor receptor 2-positive breast cancer: results from the randomized phase III adjuvant lapatinib and/or trastuzumab treatment optimization trial. J Clin Oncol. 2016;34(10):1034-42.

53. Llombart-Cussac A, Cortes J, Pare L, Galvan P, Bermejo B, Martinez N, et al. HER2-enriched subtype as a predictor of pathological complete response following trastuzumab and lapatinib without chemotherapy in early-stage HER2-positive breast cancer (PAMELA): an open-label, single-group, multicentre, phase 2 trial. Lancet Oncol. 2017;18(4):545-54.

54. Giacchetti S, Hamy AS, Delaloge S, Brain E, Berger F, Sigal-Zafrani B, et al. Long-term outcome of the REMAGUS 02 trial, a multicenter randomised phase II trial in locally advanced breast cancer patients treated with neoadjuvant chemotherapy with or without celecoxib or trastuzumab according to HER2 status. Eur J Cancer. 2017;75:323-32.

55. van Ramshorst MS, van Werkhoven E, Mandjes IAM, Schot M, Wesseling $J$, Vrancken Peeters $\mathrm{M}$, et al. Trastuzumab in combination with weekly paclitaxel and carboplatin as neo-adjuvant treatment for HER2-positive breast cancer: the TRAIN-study. Eur J Cancer. 2017;74:47-54. 
56. Pivot X, Fumoleau P, Pierga JY, Delaloge S, Bonnefoi H, Bachelot T, et al. Superimposable outcomes for sequential and concomitant administration of adjuvant trastuzumab in HER2-positive breast cancer: results from the SIGNAL/PHARE prospective cohort. Eur J Cancer. 2017:81:151-60

57. Cortes J, Fumoleau P, Bianchi GV, Petrella TM, Gelmon K, Pivot X, et al. Pertuzumab monotherapy after trastuzumab-based treatment and subsequent reintroduction of trastuzumab: activity and tolerability in patients with advanced human epidermal growth factor receptor 2-positive breast cancer. J Clin Oncol. 2012;30(14):1594-600.

58. Gianni L, Pienkowski T, Im YH, Roman L, Tseng LM, Liu MC, et al. Efficacy and safety of neoadjuvant pertuzumab and trastuzumab in women with locally advanced, inflammatory, or early HER2-positive breast cancer (NeoSphere): a randomised multicentre, open-label, phase 2 trial. Lancet Oncol. 2012:13(1):25-32.

59. Gianni L, Pienkowski T, Im YH, Tseng LM, Liu MC, Lluch A, et al. 5-year analysis of neoadjuvant pertuzumab and trastuzumab in patients with locally advanced, inflammatory, or early-stage HER2-positive breast cancer (NeoSphere): a multicentre, open-label, phase 2 randomised trial. Lancet Oncol. 2016;17(6):791-800.

60. Bianchini G, Pusztai L, Pienkowski T, Im YH, Bianchi GV, Tseng LM, et al. Immune modulation of pathologic complete response after neoadjuvant HER2-directed therapies in the NeoSphere trial. Ann Oncol. 2015;26(12):2429-36.

61. Baselga J, Swain SM. CLEOPATRA: a phase III evaluation of pertuzumab and trastuzumab for HER2-positive metastatic breast cancer. Clin Breast Cancer. 2010;10(6):489-91.

62. Swain SM, Baselga J, Kim SB, Ro J, Semiglazov V, Campone M, et al. Pertuzumab, trastuzumab, and docetaxel in HER2-positive metastatic breast cancer. N Engl J Med. 2015;372(8):724-34.

63. Baselga J, Cortes J, Kim SB, Im SA, Hegg R, Im YH, et al. Pertuzumab plus trastuzumab plus docetaxel for metastatic breast cancer. N Engl I Med. 2012;366(2):109-19.

64. Cortes J, Baselga J, Im YH, Im SA, Pivot X, Ross G, et al. Health-related quality-of-life assessment in CLEOPATRA, a phase III study combining pertuzumab with trastuzumab and docetaxel in metastatic breast cancer. Ann Oncol. 2013;24(10):2630-5.

65. Swain SM, Baselga J, Miles D, Im YH, Quah C, Lee LF, et al. Incidence of central nervous system metastases in patients with HER2-positive metastatic breast cancer treated with pertuzumab, trastuzumab, and docetaxel: results from the randomized phase III study CLEOPATRA. Ann Oncol. 2014;25(6):1116-21.

66. Luen SJ, Salgado R, Fox S, Savas P, Eng-Wong J, Clark E, et al. Tumourinfiltrating lymphocytes in advanced HER2-positive breast cancer treated with pertuzumab or placebo in addition to trastuzumab and docetaxel: a retrospective analysis of the CLEOPATRA study. Lancet Oncol. 2017;18(1):52-62

67. Baselga J, Cortes J, Im SA, Clark E, Ross G, Kiermaier A, et al. Biomarker analyses in CLEOPATRA: a phase III, placebo-controlled study of pertuzumab in human epidermal growth factor receptor 2-positive, first-line metastatic breast cancer. J Clin Oncol. 2014;32(33):3753-61.

68. Schneeweiss A, Chia S, Hickish T, Harvey V, Eniu A, Hegg R, et al. Pertuzumab plus trastuzumab in combination with standard neoadjuvant anthracycline-containing and anthracycline-free chemotherapy regimens in patients with HER2-positive early breast cancer: a randomized phase II cardiac safety study (TRYPHAENA). Ann Oncol. 2013:24(9):2278-84

69. Schneeweiss A, Chia S, Hegg R, Tausch C, Deb R, Ratnayake J, et al. Evaluating the predictive value of biomarkers for efficacy outcomes in response to pertuzumab- and trastuzumab-based therapy: an exploratory analysis of the TRYPHAENA study. Breast Cancer Res. 2014;16(4):R73.

70. Swain SM, Schneeweiss A, Gianni L, Gao JJ, Stein A, Waldron-Lynch $M$, et al. Incidence and management of diarrhea in patients with HER2-positive breast cancer treated with pertuzumab. Ann Oncol. 2017:28(4):761-8

71. Lewis Phillips GD, Li G, Dugger DL, Crocker LM, Parsons KL, Mai E, et al. Targeting HER2-positive breast cancer with trastuzumab-DM1, an antibody-cytotoxic drug conjugate. Cancer Res. 2008;68(22):9280-90.

72. Hu X, Huang W, Fan M. Emerging therapies for breast cancer. J Hematol Oncol. 2017;10(1):98.
73. Junttila TT, Li G, Parsons K, Phillips GL, Sliwkowski MX. TrastuzumabDM1 (T-DM1) retains all the mechanisms of action of trastuzumab and efficiently inhibits growth of lapatinib insensitive breast cancer. Breast Cancer Res Treat. 2011;128(2):347-56.

74. Verma S, Miles D, Gianni L, Krop IE, Welslau M, Baselga J, et al. Trastuzumab emtansine for HER2-positive advanced breast cancer. N Engl J Med. 2012;367(19):1783-91.

75. Wang Y, Fan S, Zhong W, Zhou X, Li S. Development and properties of valine-alanine based antibody-drug conjugates with monomethyl auristatin E as the potent payload. Int J Mol Sci. 2017;18(9):1860.

76. Okines A, Irfan T, Khabra K, Smith I, O'Brien M, Parton M, et al. Development and responses of brain metastases during treatment with trastuzumab emtansine (T-DM1) for HER2 positive advanced breast cancer: a single institution experience. Breast J. 2017. https://doi.org/10.1111/ tbj.12906.

77. Phillips GD, Fields CT, Li G, Dowbenko D, Schaefer G, Miller K, et al. Dual targeting of HER2-positive cancer with trastuzumab emtansine and pertuzumab: critical role for neuregulin blockade in antitumor response to combination therapy. Clin Cancer Res. 2014;20(2):456-68.

78. Krop IE, Modi S, LoRusso PM, Pegram M, Guardino E, Althaus B, et al. Phase 1b/2a study of trastuzumab emtansine (T-DM1), paclitaxel, and pertuzumab in HER2-positive metastatic breast cancer. Breast Cancer Res. 2016;18(1):34

79. Verma S, Miles D, Gianni L, Krop IE, Welslau M, Baselga J, et al. Trastuzumab emtansine for HER2-positive advanced breast cancer. N Engl J Med. 2013;368(25):1783-91.

80. Dieras V, Miles D, Verma S, Pegram M, Welslau M, Baselga J, et al. Trastuzumab emtansine versus capecitabine plus lapatinib in patients with previously treated HER2-positive advanced breast cancer (EMILIA): a descriptive analysis of final overall survival results from a randomised, open-label, phase 3 trial. Lancet Oncol. 2017;18(6):732-42.

81. Thuss-Patience PC, Shah MA, Ohtsu A, Van Cutsem E, Ajani JA, Castro H, et al. Trastuzumab emtansine versus taxane use for previously treated HER2-positive locally advanced or metastatic gastric or gastro-oesophageal junction adenocarcinoma (GATSBY): an international randomised, open-label, adaptive, phase 2/3 study. Lancet Oncol. 2017;18(5):640-53.

82. Krop IE, Kim SB, Gonzalez-Martin A, LoRusso PM, Ferrero JM, Smitt M, et al. Trastuzumab emtansine versus treatment of physician's choice for pretreated HER2-positive advanced breast cancer (TH3RESA): a randomised, open-label, phase 3 trial. Lancet Oncol. 2014;15(7):689-99.

83. Krop IE, Kim SB, Martin AG, LoRusso PM, Ferrero JM, Badovinac-Crnjevic $T$, et al. Trastuzumab emtansine versus treatment of physician's choice in patients with previously treated HER2-positive metastatic breast cancer (TH3RESA): final overall survival results from a randomised openlabel phase 3 trial. Lancet Oncol. 2017;18(6):743-54.

84. Perez EA, Barrios C, Eiermann W, Toi M, Im YH, Conte P, et al. Trastuzumab emtansine with or without pertuzumab versus trastuzumab plus taxane for human epidermal growth factor receptor 2-positive, advanced breast cancer: primary results from the phase III MARIANNE study. J Clin Oncol. 2017;35(2):141-8.

85. Bang YJ, Giaccone G, Im SA, Oh DY, Bauer TM, Nordstrom JL, et al. First-in-human phase 1 study of margetuximab (MGAH22), an FCmodified chimeric monoclonal antibody, in patients with HER2-positive advanced solid tumors. Ann Oncol. 2017;28(4):855-61.

86. Ko BK, Lee SY, Lee YH, Hwang IS, Persson H, Rockberg J, et al. Combination of novel HER2-targeting antibody 1 E11 with trastuzumab shows synergistic antitumor activity in HER2-positive gastric cancer. Mol Oncol. 2015;9(2):398-408.

87. Espelin CW, Leonard SC, Geretti E, Wickham TJ, Hendriks BS. Dual HER2 targeting with trastuzumab and liposomal-encapsulated doxorubicin (MM-302) demonstrates synergistic antitumor activity in breast and gastric cancer. Cancer Res. 2016;76(6):1517-27.

88. Miller K, Cortes J, Hurvitz SA, Krop IE, Tripathy D, Verma S, et al. HERMIONE: a randomized phase 2 trial of MM-302 plus trastuzumab versus chemotherapy of physician's choice plus trastuzumab in patients with previously treated, anthracycline-naive, HER2-positive, locally advanced/metastatic breast cancer. BMC Cancer. 2016;16:352.

89. Elgersma RC, Coumans RG, Huijbregts T, Menge WM, Joosten JA, Spijker $\mathrm{HJ}$, et al. Design, synthesis, and evaluation of linker-duocarmycin payloads: toward selection of HER2-targeting antibody-drug conjugate SYD985. Mol Pharm. 2015;12(6):1813-35. 
90. Menderes G, Bonazzoli E, Bellone S, Black J, Predolini F, Pettinella F, et al. SYD985, a novel duocarmycin-based HER2-targeting antibody-drug conjugate, shows antitumor activity in uterine and ovarian carcinosarcoma with HER2/Neu expression. Clin Cancer Res. 2017;23(19):5836-45.

91. Menderes G, Bonazzoli E, Bellone S, Black J, Altwerger G, Masserdotti A, et al. SYD985, a novel duocarmycin-based HER2-targeting antibody-drug conjugate, shows promising antitumor activity in epithelial ovarian carcinoma with HER2/Neu expression. Gynecol Oncol. 2017;146(1):179-86.

92. Black J, Menderes G, Bellone S, Schwab CL, Bonazzoli E, Ferrari F, et al. SYD985, a novel duocarmycin-based HER2-targeting antibody-drug conjugate, shows antitumor activity in uterine serous carcinoma with HER2/Neu expression. Mol Cancer Ther. 2016;15(8):1900-9.

93. van der Lee MM, Groothuis PG, Ubink R, van der Vleuten MA, van Achterberg TA, Loosveld EM, et al. The preclinical profile of the duocarmycin-based HER2-targeting ADC SYD985 predicts for clinical benefit in low HER2-expressing breast cancers. Mol Cancer Ther. 2015;14(3):692-703.

94. Ogitani Y, Hagihara K, Oitate M, Naito H, Agatsuma T. Bystander killing effect of DS-8201a, a novel anti-human epidermal growth factor receptor 2 antibody-drug conjugate, in tumors with human epidermal growth factor receptor 2 heterogeneity. Cancer Sci. 2016;107(7):1039-46.

95. Takegawa N, Nonagase Y, Yonesaka K, Sakai K, Maenishi O, Ogitani Y, et al. DS-8201a, a new HER2-targeting antibody-drug conjugate incorporating a novel DNA topoisomerase I inhibitor, overcomes HER2-positive gastric cancer T-DM1 resistance. Int J Cancer. 2017;141 (8):1682-9.

96. Bergstrom DA, Bodyak N, Park PU, Yurkovetskiy A, Devit M, Yin M, et al. P4-14-28: XMT-1522 induces tumor regressions in pre-clinical models representing HER2-positive and HER2 low-expressing breast cancer. Cancer Res. 2016;76(4 Supplement).

97. Jager M, Schoberth A, Ruf P, Hess J, Lindhofer H. The trifunctional antibody ertumaxomab destroys tumor cells that express low levels of human epidermal growth factor receptor 2. Cancer Res. 2009;69(10):4270-6

98. Diermeier-Daucher S, Ortmann O, Buchholz S, Brockhoff G. Trifunctional antibody ertumaxomab: non-immunological effects on Her2 receptor activity and downstream signaling. MAbs. 2012;4(5):614-22.

99. Schroeder P, Lindemann C, Dettmar K, Brieger J, Gosepath J, Pogorzelski $B$, et al. Trifunctional antibodies induce efficient antitumour activity with immune cells from head and neck squamous cell carcinoma patients after radio-chemotherapy treatment. Clin Transl Oncol. 2011;13(12):889-98.

100. Kiewe P, Hasmuller S, Kahlert S, Heinrigs M, Rack B, Marme A, et al. Phase I trial of the trifunctional anti-HER2 $\times$ anti-CD3 antibody ertumaxomab in metastatic breast cancer. Clin Cancer Res. 2006:12(10):3085-91.

101. Haense N, Atmaca A, Pauligk C, Steinmetz K, Marme F, Haag GM, et al. A phase I trial of the trifunctional anti Her2 $x$ anti CD3 antibody ertumaxomab in patients with advanced solid tumors. BMC Cancer. 2016;16:420.

102. Kol A, van Scheltinga AGT, Timmer-Bosscha $H$, Lamberts $L E$, Bensch $F$, de Vries EG, et al. HER3, serious partner in crime: therapeutic approaches and potential biomarkers for effect of HER3-targeting. Pharmacol Ther. 2014;143(1):1-11.

103. Lin SY, Makino K, Xia W, Matin A, Wen Y, Kwong KY, et al. Nuclear localization of EGF receptor and its potential new role as a transcription factor. Nat Cell Biol. 2001;3(9):802-8.

104. McDonagh CF, Huhalov A, Harms BD, Adams S, Paragas V, Oyama S, et al. Antitumor activity of a novel bispecific antibody that targets the ErbB2/ErbB3 oncogenic unit and inhibits heregulin-induced activation of ErbB3. Mol Cancer Ther. 2012;11(3):582-93.

105. VuT, Sliwkowski MX, Claret FX. Personalized drug combinations to overcome trastuzumab resistance in HER2-positive breast cancer. Biochim Biophys Acta. 2014;1846(2):353-65.
106. Zhang B, Lahdenranta J, Du J, Kirouac D, Nguyen S, Overland R, et al. Abstract 4633: MM-111, a bispecific HER2 and HER3 antibody, synergistically combines with trastuzumab and paclitaxel in preclinical models of gastric cancer. Cancer Res. 2013;73(8 Supplement):4633.

107. Kirouac DC, Du JY, Lahdenranta J, Overland R, Yarar D, Paragas V, et al. Computational modeling of ERBB2-amplified breast cancer identifies combined ErbB2/3 blockade as superior to the combination of MEK and AKT inhibitors. Sci Signal. 2013;6(288):ra68.

108. Zhang B, Nguyen S, Huhalov A, Nielsen UB, Niyikiza C, Mcdonagh CF, et al. Abstract 1888: MM-111, a bispecific HER2 and HER3 antibody, inhibits trastuzumab-resistant tumor cell growth. Cancer Res. 2012;72(8 Supplement): 1888.

109. Grabert RC, Cousens LP, Smith JA, Olson S, Gall J, Young WB, et al. Human T cells armed with Her2/neu bispecific antibodies divide, are cytotoxic, and secrete cytokines with repeated stimulation. Clin Cancer Res. 2006;12(2):569-76.

110. Thakur A, Norkina O, Lum LG. In vitro synthesis of primary specific anti-breast cancer antibodies by normal human peripheral blood mononuclear cells. Cancer Immunol Immunother. 2011;60(12):1707-20

111. Han H, Ma J, Zhang K, Li W, Liu C, Zhang Y, et al. Bispecific antiCD3 $\times$ anti-HER2 antibody mediates T cell cytolytic activity to HER2-positive colorectal cancer in vitro and in vivo. Int J Oncol. 2014;45(6):2446-54.

112. Ma J, Han H, Liu D, Li W, Feng H, Xue X, et al. HER2 as a promising target for cytotoxicity $T$ cells in human melanoma therapy. PLOS ONE. 2013:8(8):e73261.

113. Zitron IM, Thakur A, Norkina O, Barger GR, Lum LG, Mittal S. Targeting and killing of glioblastoma with activated $T$ cells armed with bispecific antibodies. BMC Cancer. 2013;13:83.

114. Vaishampayan U, Thakur A, Rathore R, Kouttab N, Lum LG. Phase I study of anti-CD3 $\times$ anti-Her2 bispecific antibody in metastatic castrate resistant prostate cancer patients. Prostate Cancer. 2015;2015:285193.

115. Lum LG, Thakur A, Al-Kadhimi Z, Colvin GA, Cummings FJ, Legare RD, et al. Targeted T-cell therapy in stage IV breast cancer: a phase I clinical trial. Clin Cancer Res. 2015;21(10):2305-14.

116. De Nardis C, Hendriks LJA, Poirier E, Arvinte T, Gros P, Bakker ABH, et al. A new approach for generating bispecific antibodies based on a common light chain format and the stable architecture of human immunoglobulin G1. J Biol Chem. 2017;292(35):14706-17.

117. Calvo E, Alsina M, Schellens JH, Huitema AD, Tabernero J, Vries-Schultink $A D$, et al. A phase I/II study of MCLA-128, a full length IgG1 bispecific antibody targeting HER2/HER3, in patients with solid tumors. In: American Association for Cancer Research: 2016; 2016.

118. Croset A, Macoin J, Ollier R, Pluess M, Delon C, Skegro D, et al. GBR1302: a BEAT (R) bispecific antibody for the treatment of HER2 positive cancers. Eur J Cancer. 2014;50(6):48.

119. Hausman DF, Hamilton EP, Beeram M, Thimmarayappa J, Ng G, MericBernstam F. Phase 1 study of ZW25, a bispecific anti-HER2 antibody, in patients with advanced HER2-expressing cancers. J Clin Oncol. 2017;35(4_suppl):TPS215.

120. Stockmeyer B, Valerius T, Repp R, Heijnen IA, Buhring HJ, Deo YM, et al. Preclinical studies with $\mathrm{Fc}($ gamma)R bispecific antibodies and granulocyte colony-stimulating factor-primed neutrophils as effector cells against HER-2/neu overexpressing breast cancer. Cancer Res. 1997:57(4):696-701

121. Chan JK, Hamilton CA, Cheung MK, Karimi M, Baker J, Gall JM, et al. Enhanced killing of primary ovarian cancer by retargeting autologous cytokine-induced killer cells with bispecific antibodies: a preclinical study. Clin Cancer Res. 2006;12(6):1859-67.

122. Dorvillius M, Garambois V, Pourquier D, Gutowski M, Rouanet P, Mani $\mathrm{JC}$, et al. Targeting of human breast cancer by a bispecific antibody directed against two tumour-associated antigens: ErbB-2 and carcinoembryonic antigen. Tumour Biol. 2002;23(6):337-47. 